\title{
Main pests and diseases affecting black pepper in family production systems in Capitão Poço, Pará, Brazil
}

\author{
Luane Laíse Oliveira Ribeiro ${ }^{1 *}$, Letícia do Socorro Cunha ${ }^{1}$, Felipe Cunha do Rego ${ }^{2}$, Francisco Lailson da \\ Silva de Oliveira ${ }^{2}$, Alysson Oliveira de Carvalho' ${ }^{1}$, Luã Souza de Oliveira ${ }^{2}$, Marcos Vinicius Reis de Oliveira \\ Junior $^{2}$, Jéssica da Silva Schimidt ${ }^{1}$, Fernanda Ludmyla Barbosa de Souza ${ }^{1}$, Emerson Fey ${ }^{1}$, Wanderson \\ Cunha Pereira ${ }^{2}$ and Francisca das Chagas Bezerra ${ }^{2}$
}

${ }^{1}$ Western Paraná State University, Marechal Cândido Rondon, PR, Brazil.

${ }^{2}$ Federal Rural University of Amazonia, Capitão Poço, PA, Brazil. *Author for correspondence: luanelaiseifpa@hotmail.com

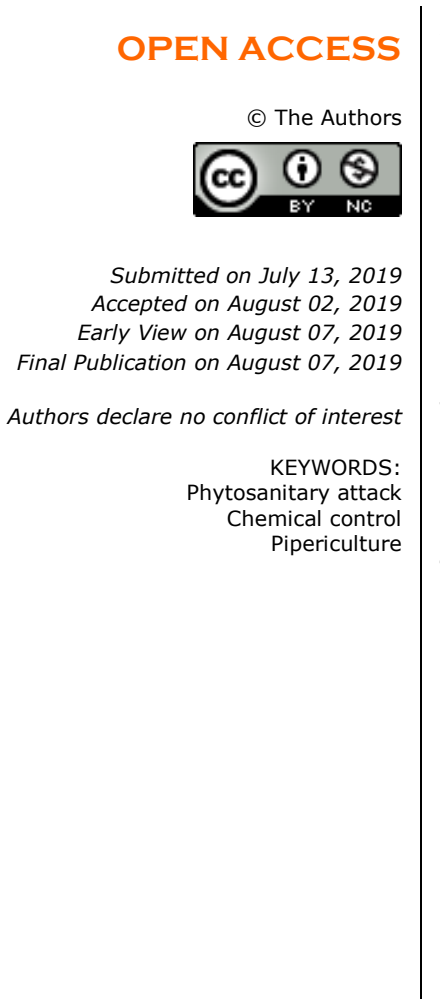

\section{ABSTRACT}

One of the main problems faced by black pepper crop in the state of Pará is the phytosanitary attack that, if not controlled and / or avoided, can cause serious damages to the crop, causing productivity and financial losses for family farmers. In the city of Capitão Poço, state of Pará, pipericutura is one of the activities that contributes to complement the income of family producers, since they also work with other agricultural species. This study aimed to make a survey of the main pests and diseases most commonly found in black pepper crop by reflecting on the control methods used by family farmers in the city of Capitão Poço/PA. To collect the information, a semi-structured questionnaire was applied to 50 family farmers in the municipality, in order to identify the main phytosanitary problems faced by family producers during the cultivation of black pepper and the most used forms of control. The most common pests and diseases are aphis $(70 \%)$ and mealybugs $(8 \%)$ and fusarium $(80 \%)$ and bacterial halo (14\%) respectively, and the use of chemicals is the main form of control used. The need for the use of new techniques that minimize and / or replace chemical control is notorious, and public and private institutions may be acting in this direction, with the development of research and its dissemination, presenting other prevention and control alternatives that can be used. meet the wishes of the municipality's producers.

\section{Highlighted Conclusions}

1. The main pests and diseases that attack the cultivation of black pepper are aphids, mealybugs, fusariosis and burning wire, using the chemical method of control.

2. It is necessary to use alternative and more sustainable techniques for pest and disease prevention and control and public and private institutions may be acting with the producers of the municipality in this aspect.

\section{INTRODUCTION}

Originated from India, black pepper (Piper nigrum L.) is one of the main agricultural products in the Amazon region's export agenda, making Brazil the fourth largest producer in the world, especially in the form of black pepper, which is the main marketing product (Andrade et al. 2017). About $85 \%$ of national production comes from family farming, generating 30,000 direct jobs during the year, and reaching 80 thousand at harvest time. It has high economic value and is widely used in agroindustry, food and chemical industry (Assis et al. 2015).

In the state of Pará, black pepper has been cultivated since the 1950. The favorable soil and climate conditions for its development have made it one of the main economic activities of Pará agriculture (Filgueiras et al. 2009).

One of the main problems faced by black pepper crop in the state is the phytosanitary attack that if not controlled and/or avoided can cause serious damage to the crop, causing loss of productivity and financial for family farmers.

In this sense, Pará is the largest producer of this spice, having the municipality of Capitão Poço a significant representation in this scenario. In that city, pipericutura is one of the activities that contributes to complement the income of family producers, since they also work with other agricultural species. 
Even though it is an important crop in terms of socioeconomic aspects, studies that present the bottlenecks in phytosanitary terms that affect the cultivation of black pepper of small producers of the municipality still need to be developed, since the lack of research on the subject also reveal the lack of knowledge about this.

In this sense, the present study aimed to make a survey of the main pests and diseases that occur in the black pepper crop, reflecting on the control methods used by family farmers in the city of Capitão Poço, PA, Brazil.

\section{MATERIAL AND METHODS}

The field research was carried out from December 2018 to January 2019, with family producers who cultivate black pepper in the city of Capitão Poço / PA. In this city, the pepper is predominantly worked by small producers who have the pipericulture as one of the family incomes generating activities.

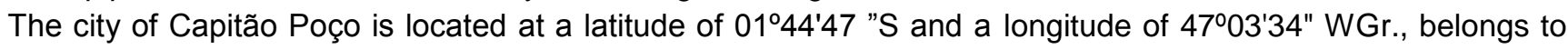
Microregion of Guamá, northeastern mesoregion of Pará and is $226 \mathrm{~km}$ from the capital Belém, with an average annual temperature of $26.2^{\circ} \mathrm{C}$ and according to the Köeppen classification the Ami type climate (Silva et al. 2011), with annual precipitation around $2,500 \mathrm{~mm}$ and relative air humidity between $75 \%$ and $89 \%$, in the months with the lowest and highest precipitation, respectively (Schwart 2007).

The research was developed based on the application of a semi-structured questionnaire in order to identify the main phytosanitary problems faced by family farmers during the cultivation of black pepper, the most used forms of control, thus reflecting on this problem and proposing alternatives that will minimize the damage caused by these phytopathogens. For this, 50 producers who work directly with this crop were randomly interviewed.

In the course of the study, in addition to the questionnaire, we also used audio recording, notes in field notebooks and direct and indirect observations that served as support for information collection and subsequent research rationale.

Data were organized in a Microsoft Excel $2013 \AA$ spreadsheet, where they were manipulated to elaborate the table. Finally, the interpretation and analysis of the qualitative information obtained was performed.

\section{RESULTS AND DISCUSSION}

Table 1 presents the main phytosanitary problems that occur in the peppers of small producers in the municipality.

Table 1. Main pests that attack black pepper in family production systems in Capitão Poço, PA, Brazil.

\begin{tabular}{lcc}
\hline \multirow{2}{*}{ Black pepper pests } & \multicolumn{3}{c}{ Incidence (\%) } \\
\cline { 2 - 3 } & Diseases & Pests \\
\hline Rod drill & - & 8 \\
Aphids & - & 70 \\
Mealybugs & - & 18 \\
Others & - & 4 \\
\hline Black pepper diseases & & - \\
\hline Fusarium & 80 & - \\
Withered yellow & 14 & - \\
Burning wire & 2 & - \\
Anthracnose & 2 & - \\
Others & 2 & 100 \\
\hline Total & 100 & \\
\hline
\end{tabular}

The most common pests are aphids and mealybugs. The incidence of these phytopathogens is about 70 and $18 \%$ respectively. The attack of these pests account for a total of $88 \%$ of the damage caused to black pepper crop, which if not controlled, can cause significant damage, causing serious productivity losses.

Aphids infest all stages of pepper development, especially in the rainy season. These suck the sap of the leaves and buds, causing curling and difficulty of plant development, especially at the beginning of growth. Mealybugs-infested plants, on the other hand, may wither, dropping buds and leaves, and even die. Their attacks are more common in poorly tended crops and with the adoption of wrong cultural treatments (Lemos et al. 2014).

According to Tremacoldi (2010), among the diseases that attack the black pepper crop, the ones that cause the greatest economic damage to farmers are root fusarium or rot (Fusarium solani f.sp. piperis) and withered yellow 
(Fusarium oxysporum). However, there are other diseases that cause less damage to the pepper plants such as wire burn (Koleroga noxia) and anthracnose (Colletotrichum gloeosporioides).

The most significant diseases in black pepper crop are fusarium and aureolated stain, representing about 80 and $14 \%$ respectively.

Fusarium is a serious disease that can do a lot of damage to a black pepper, with an annual reduction of $3 \%$ in cultivated area and production. As a consequence, the crop cycle, which lasts an average of 12 years, has changed and become shorter, with an average of five to six years of survival in the area of disease occurrence (Lemos et al. 2011). This makes the maintenance of the crop very difficult, especially for family farmers, who do not have the return due to the high investment made in planting, because there are no resistant commercial cultivars or effective chemical control for the disease. The disease causes root rot, yellowing and leaf wilting, which fall to the ground or necrotize and become attached to the season.

Withered yellow, while occurring in only a few cultivars, can cause a pepper to die in a short time because it spreads rapidly among plants. The main symptoms are discoloration of the stem and branches and yellowing and leaf fall and triangular lesions appear on the branches in the knot region, necrosing only one side of the stem, becoming half green and half black (Lemos et al. 2014).

When asked about the control methods used, all farmers pointed to chemical control as a way to combat phytopathogens. To date, there is no effective chemical treatment against Fusarium or commercial fusariumresistant black pepper cultivars (Tremacoldi 2010). However, alternative methods or products have been partially tested in order to take advantage of their antibiotic activities (fungicides and fungistatic) in the control of plant diseases. The search for alternative methods / products for disease management, replacing conventional methods, has been increasing in recent years, due to the harmful effects that pesticides cause to the environment and human health. Thus, studies for the control of fusarium using alternative methods are concerned with the strategies of modern agriculture and are directed towards economic and ecological interests.

In this context, the need for the development of new alternative control techniques is noticeable, since the use of agrochemical causes a series of impacts and imbalances both for the environment and for those who manipulate these substances.

It is in this scenario that public and private institutions could presently develop and foster the use of more sustainable alternatives for control and / or prevention, with the adoption of Integrated Pest Management (IPM), the use of natural syrup (the neem stratum that still needs much research that prove the effectiveness of fusarium control and even biological control since these practices would bring greater balance in the production system and better welfare for producers.

In addition, care in the production/acquisition of seedlings and management of peppers, as well as the adoption of practices aimed at diversifying production would be strategies that could act in a preventive manner in order to minimize pest attack and disease outbreaks the main strategy that must be adopted. A nutritionally balanced system combined with factors such as management and other practices can contribute to reducing the appearance of these problems in the cultivation of black pepper.

The use of varieties resistant to pest and disease attack generally reveals positive impacts on both economic, social and environmental aspects, however, farmers need more information and access to this technology.

In this sense, it was found that the main pests and diseases that attack the cultivation of black pepper were aphids, mealybugs, fusarium and burning wire, being the chemical control method the one used predominantly since this is the more accessible to producers.

Thus, the need for the use of new techniques that minimize and/or replace the chemical control is notorious and the public and private institutions may be acting in this direction, with the development of research and its disclosure, presenting other prevention alternatives and control that meet the wishes of the municipality's producers.

\section{Acknowledgments}

To the producers who received us on their properties and provided the information necessary for this work and the commitment of all the authors involved.

\section{References}

Andrade CGC et al. 2017. Impacting factors on the raw value of black pepper (Piper nigrum L.) production in Pará. Floresta e Ambiente 24: e00145615.

Assis BVR et al. 2015. Inhibitory effect of Piper nigrum L. extract on corrosion of carbon steel in acid medium. Revista Virtual de Química 5:1830-1840. 
Filgueiras GC et al. 2009. Conjuncture of the black pepper market in Brazil and worldwide. In: Workshop da pimenta do reino do estado do Pará. Belém: Embrapa. Available at: https://www.alice.cnptia.embrapa.br/handle/doc/660437. Accessed on Jul. 13, 2019.

Lemos OF et al. 2011. Conservação e melhoramento genético da pimenteira-do-reino (Piper nigrum L.) em associação com as técnicas de biotecnologia. Belém do Pará: Embrapa.

Lemos OF de et al. 2014. Boas práticas agrícolas para aumento da produtividade e qualidade da pimenta-do-reino no Estado do Pará. Brasília: Embrapa.

Silva AG et al. 2011. Citrus blackfly infestation in citrus orchards, in conventional and agroforestry systems. Revista Brasileira de Fruticultura 33:053-060

Schwart G. 2007. Sustainable management of secondary forests: potential species in Northeastern Pará, Brazil. Amazônia: Ciência e Desenvolvimento 3:125-147.

Tremacoldi CR. 2010. principais doenças fúngicas da pimenteira-do-reino no Estado do Pará e recomendações de controle. Belém do Pará: Embrapa. 